\title{
Puccinia sambuci Infection of American Elderberry Plants
}

\author{
Michele R. Warmund ${ }^{1}$, Jeanne D. Mihail, and Kaley Hensel \\ Division of Plant Sciences, University of Missouri, Columbia, MO 65211
}

Additional index words. Carex frankii, Sambucus nigra subsp. canadensis, fungal pathogen, sedge, fruit quality, vegetative growth

\begin{abstract}
Elderberry rust (Puccinia sambuci Schwein.) Arthur (=P. bolleyana) (Arthur, 1921) disease is frequently found in commercial American elderberry (Sambucus nigra $\mathrm{L}$. subsp. canadensis L.) plantings when an alternate host, Carex sp., is present. To evaluate potential infection periods of $P$. sambuci on elderberry plants, micrometeorological conditions were monitored. Rust symptoms were observed on elderberry on 5 Apr. 2016, and conditions favorable for possible infection were 9 to $18^{\circ} \mathrm{C}, \geq 3$ hours of continuous leaf wetness, and $\geq 85 \%$ relative humidity. Studies were also conducted to ascertain whether $P$. sambuci with varying pustule numbers affects fruiting, berry puree quality, or vegetative growth. Fruit yield was reduced by $31 \%$ when potted 'Bob Gordon' elderberry averaged six rust pustules per plant compared with noninfected plants. In another experiment, field-grown 'Wyldewood' plants averaging 137 rust pustules/cane at harvest had $47 \%$ less fruit weight on canes than uninfected canes. Titratable acidity of fruit puree from plants was lower when plants had either 690 rust pustules/plant or 137/ pustules/cane, but soluble solids and pH of puree were unaffected by $P$. sambuci infection. The effect of rust infection on vegetative growth of elderberry plants also varied with pustule numbers. With a low infection level (six pustules per plant), $P$. sambuci did not induce premature leaf loss on 'Bob Gordon' plants or adversely affect shoot dry weight at the end of the growing season. When $P$. sambuci infection on 'Wyldewood' plants was more severe (137 pustules/cane), greater leaf loss occurred on infected canes than on uninfected canes. At very high infection levels (690 pustules/plant), 'Bob Gordon' plant dry weight was reduced. Because of the potential for fruit yield loss on elderberry plants, control of $P$. sambuci at relatively low infection levels on this plant may be warranted. Strategies that eliminate or suppress the alternate host would likely reduce the $P$. sambuci inoculum and limit the potential for elderberry plant infection.
\end{abstract}

Elderberry [Sambucus nigra L. ssp. canadensis (L.) Bolli] is a high-value crop that is grown and processed into products for niche markets (Charlebois et al., 2010; Mohebalian et al., 2012). Elderberry plants are fruitbearing, multi-stemmed shrubs with compound leaves native to eastern and central North America. Inflorescences are indeterminate compound umbels, where the outer fruit is the first to mature (Zomlefer, 1994). With the increasing production of elderberry, wild germplasm with vigorous vegetative growth and a high number of umbels with large fruit size has been selected to enhance yields. 'Wyldewood', a cultivar that matures during the late season and has high-quality fruit, was selected near Brush Hill, OK, in 1998 (Byers et al., 2010). 'Bob Gordon', a productive midseason-ripening cultivar with pendulous umbels, was selected in Osceola, MO, in 1999 (Byers and Thomas, 2011).

Because of continuous elderberry production in a monoculture system, pests have become prevalent. Elderberry rust (Puccinia sambuci Schwein.) Arthur (P. bolleyana) is a

Received for publication 1 Jan. 2019. Accepted for publication 20 Feb. 2019.

Contribution from the Missouri Agricultural Station project 322 .

${ }^{1}$ Corresponding author. E-mail: warmundm@missouri. edu. common disease found on American elderberry that causes foliar and shoot distortion (Arthur, 1962; Kellerman, 1904; Warmund, 2017). Puccinia sambuci is a heteroecious fungus that requires two hosts, sedge (Carex spp.) and American elderberry, to complete its lifecycle (Mims, 1981; Saccardo, 1891). Of the five spore stages of $P$. sambuci, pycniospores and aeciospores develop on elderberry, whereas urediniospores, teliospores, and basidiospores develop on Carex spp. (Mims, 1981). At least 13 species of sedge have been reported as an alternate host for P. sambuci (Afshan and Khalid, 2009; Arthur, 1962).

Pycnia are the first signs observed on elderberry leaflets and petioles during early spring and appear as small yellow pustules on adaxial and abaxial surfaces of leaflets and stems. Pycnia are flask-shaped and contain receptive hyphae and pycniospores (Littlefield and Heath, 1979; Petersen, 1974). When pycniospores contact and adhere to receptive hyphae of a compatible mating type, they undergo plasmogamy, resulting in the formation of dikaryotic mycelium (Mims, 1981).

After dikaryotization, mycelia grow intercellularly on the abaxial leaf surface of elderberry plant tissue while producing intracellular haustoria to gain nutrients and develop aecia containing aeciospores (Petersen, 1974). Puccinia sambuci aecia are often observed on elderberry in May, with large yellow-orange pustules that cause deformed leaves, stems, and petioles. Aecia produce chains of aeciospores that are wind-blown to the alternate host, a Carex species (Mims, 1981).

After germination and subsequent infection of sedge leaf tissue in the summer, uredinia form on the adaxial surface of leaflets and produce urediniospores that can re-infect sedge plants (Bolley, 1889). During the late summer, uredinia develop into telia that produce two-cell, thick-wall teliospores that can withstand low winter temperatures (Arthur, 1962). During favorable environmental conditions in March or April, each cell of the teliospore germinates and produces a basidium, the site of meiosis, resulting in four haploid basidiospores that are wind-blown to elderberry plants (Petersen, 1974). Basidiospore germination occurs on elderberry tissue and a germ tube is produced, which penetrates the host directly through the cuticle and epidermis, with subsequent development of monokaryon hyphae that form pycnia (Agrios, 2005).

Although the disease cycle of $P$. sambuci has been described, the epidemiology of elderberry rust and the consequences of infection on host productivity have not been investigated. Therefore, studies were conducted to: 1) determine the effect of $P$. sambuci infection on fruiting and vegetative growth of elderberry plants; 2) compare soluble solids, $\mathrm{pH}$, and titratable acidity of berry puree from infected and uninfected plants; and 3) characterize environmental conditions associated with potential rust infection of elderberry.

\section{Materials and Methods}

Inoculation of elderberry plants in 2014. Twenty-five sedge (Carex frankii Kunth) plants producing $P$. sambuci teliospores were obtained from a commercial elderberry planting near Hartsburg, MO, on 15 Sept. 2013. Plants were placed in $8.5-\mathrm{L}$ polyethylene containers (A.M. Leonard, Piqua, $\mathrm{OH}$ ) with native soil (Haymond silt loam) and transported to the University of Missouri Horticulture and Agroforestry Research Center (HARC) near New Franklin, MO. On 26 Nov. 2013, potted plants were maintained in an isolated nursery area until they were covered with a polyethylene foam blanket (Hummert International, St. Louis, MO) and plastic sheeting for winter protection. On 20 Apr. 2014, sedge plants were uncovered.

One-year-old 'Bob Gordon' plants were obtained from a commercial nursery (Botany Shop, Joplin, MO) on 10 Mar. 2014 and were transplanted to 8.5 -L polyethylene containers using Pro-Mix BX (Premier Tech Horticulture, Quakertown, PA). Plants were pruned to a height of $30 \mathrm{~cm}$ above the medium surface, leaving three canes per plant. Dormant oil (Damoil; Drexel Chemical Company, Memphis, TN) was applied to elderberry plants at $7.5 \mathrm{~mL} \cdot \mathrm{L}^{-1}$ to control overwintered eriophyid mites (Phyllocoptes wisconsinensis Kiefer). On 14 Mar. 2014, 50 g 15N-9P-12K controlled-release fertilizer (Osmocote; Scotts 
Company, Marysville, $\mathrm{OH}$ ) was applied to the medium surface of potted elderberry plants. After $21 \mathrm{~d}$ in the nursery, eight elderberry plants were treated with propiconazole (PropiMax EC; Dow AgroSciences, Indianapolis, IN) fungicide at $11.4 \mathrm{~mL} \cdot \mathrm{L}^{-1}$. On $20 \mathrm{Apr}$., a humid environment was established by filling each 189-L polyethylene bag (HDX; Homer TLC, Wilmington, DE) with $10 \mathrm{~L}$ of water; then, the bag was sealed. Two days later, eight elderberry plants not treated with propiconazole were misted with sterile water and inoculated with $P$. sambuci. A 1-×1-cm piece of infected sedge foliage with approximately four uredinia was used to mechanically transfer fungal spores to the entire elderberry leaf surface by direct contact. A different leaf section of sedge was used to inoculate each of the six leaves per plant. Each inoculated plant was then placed on top of an inverted 7.6- $\mathrm{L}$ pot within a sealed bag for $48 \mathrm{~h}$ of incubation at $18{ }^{\circ} \mathrm{C}$ in the dark. Eight fungicide-treated elderberry plants were also misted with sterile water, sealed in bags, and incubated to serve as controls. After incubation, plants were removed from bags and arranged in a completely randomized design in the nursery area at HARC. Plants were irrigated with an overhead sprinkler system as needed to prevent moisture stress. The number of rust pustules on each leaflet was recorded on 17 June 2014. At peak ripeness (all berries were dark purple) in August, umbels were removed and the harvest dates were recorded. Berry number and fresh weights of destemmed berries were recorded before fruit was sealed in polyethylene bags and stored at $-22{ }^{\circ} \mathrm{C}$. On 1 Oct. 2014 , leaves and petioles were harvested and oven-dried for $24 \mathrm{~h}$ at $65{ }^{\circ} \mathrm{C}$ for dry weight measurements. On 13 Nov. 2014, canes were pruned to $30 \mathrm{~cm}$ above the medium surface for dry weight measurements and covered on 28 Nov. 2014 for winter protection (as previously described).

After $60 \mathrm{~d}$ in cold storage, fruit was thawed for compositional analyses. Berries from each elderberry plant were pooled and randomly sampled for analyses. To prepare each berry puree sample, $50 \mathrm{~g}$ of fruit was placed in a blender cup (Waring, Stamford, CT) with $50 \mathrm{~mL}$ of double-distilled water and processed for $30 \mathrm{~s}$. A $0.3-\mathrm{mL}$ aliquot of puree was used to determine soluble solids concentrations with a digital refractometer (Atago USA, Bellevue, WA), and a $10-\mathrm{mL}$ aliquot was used to measure $\mathrm{pH}$ (HI222; Hanna Instruments, Woonsocket, RI). To measure titratable acidity, another $10-\mathrm{mL}$ aliquot was diluted with $48 \mathrm{~mL}$ of degassed deionized water and titrated (G20 Compact Titrator; Mettler-Toledo, Columbus, $\mathrm{OH}$ ) to $8.2 \mathrm{pH}$ with $0.1 \mathrm{~N}$ of sodium hydroxide. Titratable acidity, expressed as citric acid, was then calculated.

On 1 Apr. 2015, elderberry plants were uncovered, fertilized as described, and maintained in the nursery without further $P$. sambuci inoculation. Fruit yield was recorded during Aug. 2015 (the second sea- son after infection). To determine plant dry weight, roots were washed so they were free of soil and oven-dried (as previously described) on 15 Nov. 2015.

Data for fruit yield, mean berry weight, puree characteristics, and vegetative dry weight were analyzed using the T TEST procedure of SAS software (SAS 9.4; SAS Institute Inc., Cary, NC). To test mean differences, a pooled test was used when variances were equal; the Satterthwaite test was used when variances were unequal $(P \leq 0.05)$.

Rust infection of potted 'Bob Gordon' plants in 2016. 'Bob Gordon' and 'Wyldewood' elderberry plants were obtained from a commercial source (Botany Shop, Joplin, MO) and transplanted to 8.5-L polyethylene containers at HARC on 14 Nov. 2015 (as described for the previous experiment). Plants were then covered for winter protection $12 \mathrm{~d}$ later. Sedge plants originally obtained in 2013 were also covered and overwintered in an isolated nursery area at HARC. On 11 Mar. 2016, elderberry plants were uncovered, pruned to five nodes, treated with dormant oil, and fertilized as described. For $P$. sambuci infection, elderberry plants were arranged in six experimental blocks with four symptomatic sedge plants centrally located within each block. In each cardinal direction (i.e., each north, south, east, and west) of the block, three 'Bob Gordon' elderberry plants were positioned at 23, 59, and $95 \mathrm{~cm}$ from sedge plants (Fig. 1). One block similarly arranged but without any sedge plants was used as an uninfected control treatment. For pollination, one 'Wyldewood' elderberry plant was placed in the northwest, southwest, and southeast quadrants of each block. A clear polyethylene curtain $(2.5-\mathrm{m}$-tall) was placed between blocks with and without sedge plants to prevent $P$. sambuci infection of control plants. Plants were sub-irrigated by filling 4-L saucers (Hummert International, St. Louis, MO) underneath pots as needed. Elderberry leaf and leaflet numbers were recorded on 12 Mar., 29 Apr., 19 May, and 19 Aug. 2016. Rust pustules were evaluated on 5 Apr., 29 Apr., and 19 May 2016. After aecia were observed on elderberry, all plants were moved to a nursery area with overhead irrigation and arranged in a completely randomized design on 25 July 2016. On 22 Mar. 2016 and 4 Apr. 2016, spirodiclofen (Envidor 2 SC; Bayer, Research Triangle Park, NC) was applied at $1.2 \mathrm{~mL} \cdot \mathrm{L}^{-1}$ for mite control. Dates of the first flowering for each umbel were recorded. Fruit was harvested at peak ripeness, and the date of picking was recorded. Berry numbers, fruit yield, berry composition from puree, and shoot dry weights were also obtained.

Micrometeorological data were recorded from 26 Feb. to 28 Sept. 2016, using an environmental monitoring system (U30; Onset, Bourne, MA) located $1 \mathrm{~m}$ from the rust-infected blocks. Sensors for temperature and relative humidity (S-TMB-M006; Onset, Bourne, MA), leaf wetness (S-LWAM003; Onset, Bourne, MA), and precipita-

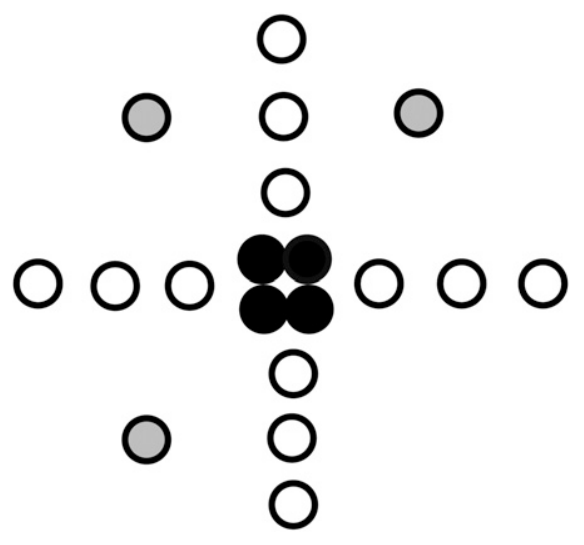

Fig. 1. One of six experimental blocks used to infect potted 'Bob Gordon' elderberry plants in 2016. Central black circles represent sedge (Carex frankii) plants used as the inoculum source, open circles represent 'Bob Gordon' elderberry plants, and the three light gray circles represent 'Wyldewood' elderberry plants used for pollination. Spacing between each potted 'Bob Gordon' pot was $10 \mathrm{~cm}$.

tion (S-RGB-M002) collected data at 10-s intervals, which were averaged and recorded at 10-min intervals. Based on the results of Beraha et al. (1960), temperatures $>8{ }^{\circ} \mathrm{C}$, relative humidity $\geq 85 \%$, and leaf wetness periods $\geq 3 \mathrm{~h}$ were considered possible infection periods.

To evaluate rust pustule development in relation to the cardinal direction and distance of elderberry plants $(1=$ closest to sedge plants; 3 = furthest from sedge plants) from the inoculum source, data for pustule number and the number of infected leaves and leaflets per plant were analyzed as a $4 \times 3$ factorial experiment using the PROC GLMMIX procedure of SAS (SAS Institute Inc.). Means were separated by Fisher's protected least significant difference test $(P \leq 0.05)$. Because of deer herbivory during the growing season, 30 'Bob Gordon' elderberry plants were excluded from the study. Therefore, the $\mathrm{T}$ TEST procedure of SAS (SAS Institute Inc.) was used to analyze the effect of $P$. sambuci on plant growth and fruiting. To test mean differences, a pooled test was used when variances were equal; the Satterthwaite test was used when variances were unequal $(P \leq 0.05)$

Natural rust infection of 'Wyldewood' elderberry canes of a commercial elderberry planting in 2016. Three-year-old 'Wyldewood' elderberry plants growing in Weller silt loam soil of a commercial planting near New Bloomfield, MO, were used for this study in 2016. Eleven elderberry canes at each of three $P$. sambuci rust infection levels (low $=10$ to 99 pustules/cane; medium $=100$ to 199 pustules/cane; high $=200$ to 299 pustules/ cane) were visually assessed, selected, and flagged on individual plants on 18 May. Eleven individual canes without visual symptoms of rust were also flagged in a completely randomized design. Total leaf number, number of $P$. sambuci-infected leaves, and number 
of pustules per leaf on each elderberry cane were recorded on 31 May.

Fruit harvest, berry number, and berry weight were recorded from 20 July to 23 Aug. 2016. Leaves on each cane were counted on 26 Aug., and the number of those lost since 18 May was calculated. Canes were pruned to $10 \mathrm{~cm}$ on 13 Oct., and the dry weight of canes with their foliage was determined. Fruit compositional analyses from berry puree were performed as described. When the harvested fruit was fewer than $50 \mathrm{~g}$ per cane, the $1: 1$ berry weight/double-distilled water volume was used to prepare the puree. A $t$ test using pooled data from rust-infected canes and uninfected canes was performed for statistical analyses of fruit yield per cane, mean berry weight, puree characteristics, leaf loss, and cane weight data.

\section{Results}

Elderberry plants inoculated in 2014. 'Bob Gordon' elderberry inoculated with $P$. sambuci averaged 690 pustules/plant by 17 June 2014, whereas no rust symptoms were observed on noninoculated plants. Infected plants had lower fruit yield, lower mean berry weight, and lower shoot dry weight than that of noninoculated controls (Table 1). Soluble solids of fruit puree were unaffected by $P$. sambuci infection. Additionally, the $\mathrm{pH}$ levels of puree from inoculated $(4.7 \mathrm{pH})$ and noninoculated $(4.8 \mathrm{pH})$ plants were similar $(P=0.21)$. However, fruit puree processed from $P$. sambuci-inoculated plants had lower titratable acidity than that from noninoculated plants. During the following growing season, plants that had been inoculated with $P$. sambuci in 2014 still had reduced yield and plant dry weight compared with those of noninoculated plants, even though rust pustules were not observed in 2015.

Potential infection periods of $P$. sambuci in 2016. Between 11 Mar., when 'Bob Gordon' elderberry plants were uncovered, and 17 May 2016, there were 30 potential infection periods, as defined by Beraha et al. (1960), with $\geq 3$ h of continuous leaf wetness, $\geq 85 \%$ relative humidity, and mean maximum hourly temperatures ranging from 9 to $18^{\circ} \mathrm{C}$ (Table 2). The minimum drying time of leaves between the possible infection periods was $>2 \mathrm{~h}$ on 12 Mar. Moreover, $269 \mathrm{~mm}$ of rainfall was recorded during 13 precipitation events. Five rust pustules were first observed on 4 of 72 elderberry plants on 5 Apr. However, by 29 Apr., 59 of 72 plants were infected with rust, with a total of 304 pustules. Rust infection continued, and 63 of 72 elderberry plants with 350 total pustules were recorded on 19 May.

Elderberry plants had relatively low levels of rust infection when evaluated on 29 Apr. (Table 3). However, elderberry plants spaced $23 \mathrm{~cm}$ from the infected sedge had more pustules per plant than those spaced at $59 \mathrm{~cm}$. Furthermore, plants spaced $23 \mathrm{~cm}$ from the infected sedge generally had more infected leaves and leaflets than those placed further away from the source of inoculum. The cardinal position of elderberry plants in each block did not affect the number of infected leaves and leaflets or pustules per plant (data not shown).

When the data of rust-infected plants were pooled, the average number of pustules per plant was six on 19 May. The first dates of flowering occurred during the last week of June and were similar for all plants (data not shown). The first (10-14 Aug.; $P=0.34$ ) and last (25-27 Aug.; $P=0.23$ ) harvest dates for rust-infected plants and uninfected plants were also similar. P. sambuci-infected plants produced a lower fruit yield with smaller berries than did noninfected plants (Table 4). When berry puree characteristics were analyzed, there were no significant differences in soluble solids content, $\mathrm{pH}$ (5.0 to 5.1), or titratable acidity (Table 4). On 19 May, the total number of leaves on rust-infected plants (37) was greater than that on uninfected plants $(31)(P=0.02)$. However, by 19 Aug., leaf numbers were similar $(P=0.21)$ among infected (77) and uninfected (73) plants. The shoot dry weight of rust-infected plants was greater than that of uninfected plants (Table 4), likely due to the greater number of leaves per plant early during the growing season.

Natural rust infection of 'Wyldewood' elderberry canes in 2016. No significant differences in fruit yield or vegetative characteristics were found among canes with three levels of rust infection. When data were pooled from rust-infected canes, the mean number of pustules per cane was 137 on 31 May 2016. The first harvest date for umbels on rust-infected canes occurred $5 \mathrm{~d}$ earlier $(6$ Aug.) than that for control canes $(P=0.02)$. The last fruit harvest date (14 Aug.) for infected canes was also $3 \mathrm{~d}$ earlier than that for control canes $(P=0.04)$. The fruit yield was reduced by rust infection, but the mean berry weights were similar among all canes (Table 5). Soluble solids and $\mathrm{pH}$ (4.4 to 4.5) of berry purees were also similar among canes. However, the titratable acidity of puree from rust-infected canes was lower than that of puree from asymptomatic canes. By 26 Aug., rust-infected canes lost more leaves but had similar cane dry weights on 13 Oct. than the controls.

\section{Discussion}

Foliar symptoms of $P$. sambuci rust (i.e., pustules) were first observed on 'Bob Gordon' elderberry plants as early as $5 \mathrm{Apr}$. Many rust pustules were observed later (29 May) on foliage and stems of 'Wyldewood' elderberry of the commercial planting, with the initial infection occurring earlier. In some cases, stem distortion occurred when numerous rust pustules were present. The numbers of pustules on leaflets and stems for each cane or plant were recorded during these studies, but the severity of stem distortion was not evaluated. Although rust pustules were also observed on a few closed flowers and pedicels before bloom through harvest on 'Wyldewood' elderberry of the field planting, canes with infected floral tissue were not included in this study. Rust infection on floral tissue, which has not been previously reported, contributed to mortality and fruit loss.

$P$. sambuci infection occurs when germinated basidiospores from sedge plants penetrate susceptible elderberry tissue under favorable environmental conditions, including high humidity or adequate moisture on the plant tissue, for a long enough time over a suitable range of temperatures. During the initial rust infection observed on 5 Apr. 2016, there were five potential infection periods before the first observation of disease symptoms and signs (Table 2). Temperatures during these periods ranged from 10.9 to $13.2^{\circ} \mathrm{C}$, and leaf wetness durations ranged from 3 to $18 \mathrm{~h}$. Of these potential infection periods, conditions occurring from 12 to 13 Mar. may have resulted in pustule development because $5.6 \mathrm{~mm}$ of precipitation occurred with $18 \mathrm{~h}$ of leaf wetness and the mean hourly temperature was $13.2{ }^{\circ} \mathrm{C}$.

The number of plants infected and the number of observed pustules (both pycnia and aecia) increased throughout April and May 2016. From 6 to 27 Apr., there were 14 potential infection periods; five of these occurred during precipitation events. Conditions from 18 to 19 Apr. may have resulted in significant infection since $58.7 \mathrm{~mm}$ of precipitation occurred with $16 \mathrm{~h}$ of leaf wetness and the mean hourly temperature was $16.2{ }^{\circ} \mathrm{C}$. From 29 Apr. to 19 May, 50 more

Table 1. Fruit characteristics, berry puree composition, and vegetative dry weights of 'Bob Gordon' elderberry plants inoculated with Puccinia sambuci or noninoculated plants in 2014. ${ }^{\mathrm{z}}$

\begin{tabular}{|c|c|c|c|c|c|c|c|}
\hline \multirow[b]{2}{*}{ Treatment } & \multicolumn{5}{|c|}{2014} & \multicolumn{2}{|c|}{2015} \\
\hline & $\begin{array}{c}\text { Fruit } \\
\text { yield/plant (g) }\end{array}$ & $\begin{array}{l}\text { Mean berry } \\
\text { wt (mg) }\end{array}$ & $\begin{array}{l}\text { Total soluble } \\
\text { solids ( }{ }^{\circ} \text { Brix) }\end{array}$ & $\begin{array}{l}\text { Titratable acidity } \\
\quad(\mathrm{g} / 100 \mathrm{~mL})\end{array}$ & $\begin{array}{c}\text { Shoot dry } \\
\text { wt (g) }\end{array}$ & $\begin{array}{c}\text { Fruit } \\
\text { yield/plant (g) }\end{array}$ & $\begin{array}{c}\text { Plant dry } \\
\text { wt }(\mathrm{g})\end{array}$ \\
\hline Inoculated & $138 \mathrm{~b}$ & $115 \mathrm{~b}$ & $10.2 \mathrm{a}$ & $0.57 \mathrm{~b}$ & $40 \mathrm{~b}$ & $185 \mathrm{~b}$ & $240 \mathrm{~b}$ \\
\hline Noninoculated & $180 \mathrm{a}$ & $146 \mathrm{a}$ & $9.9 \mathrm{a}$ & $0.63 \mathrm{a}$ & $50 \mathrm{a}$ & $235 \mathrm{a}$ & $275 \mathrm{a}$ \\
\hline
\end{tabular}

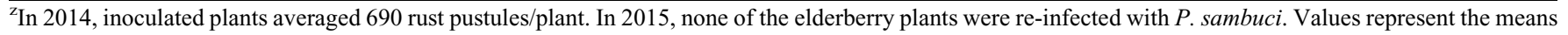
of eight replications of each treatment. Means followed by different letters in columns are significantly different $(P \leq 0.05)$. Means were separated by a Satterthwaite test when variances were unequal or by a pooled test when variances were equal. 
Table 2. Continuous elderberry leaf wetness periods with corresponding mean maximum hourly temperatures and precipitation recorded at the Horticulture and Agroforestry Research Center near New Franklin, MO, during Spring 2016.

\begin{tabular}{|c|c|c|c|}
\hline Date $^{z}$ & $\begin{array}{c}\text { Continuous leaf } \\
\text { wetness (no. hours) }\end{array}$ & $\begin{array}{l}\text { Mean hourly temp during } \\
\text { wetness period }\left({ }^{\circ} \mathrm{C}\right)\end{array}$ & $\begin{array}{c}\text { Precipitation during } \\
\text { leaf wetness period }(\mathrm{mm})\end{array}$ \\
\hline 12 Mar. & 3 & 12.5 & 3.1 \\
\hline 12-13 Mar. & 18 & 13.2 & 5.6 \\
\hline 13-14 Mar. & 13 & 10.9 & 0 \\
\hline 14-15 Mar. & 13 & 11.4 & 0 \\
\hline 31 Mar. & 7.5 & 13.1 & 5.1 \\
\hline 6 Apr. & 3 & 13.3 & 0.5 \\
\hline 10-11 Apr. & 13 & 11.9 & 17.5 \\
\hline 16 Apr. & 5 & 10.8 & 0 \\
\hline 16 Apr. & 10 & 10.8 & 0 \\
\hline 17 Apr. & 11 & 12.3 & 0 \\
\hline 18-19 Apr. & 16 & 16.2 & 58.7 \\
\hline 19-20 Apr. & 11 & 15.0 & 35.1 \\
\hline 20-21 Apr. & 13 & 9.7 & 0 \\
\hline 22 Apr. & 9 & 8.9 & 0 \\
\hline 23 Apr. & 11 & 11.4 & 0 \\
\hline 25-26 Apr. & 10 & 16.2 & 0 \\
\hline 26 Apr. & 3 & 15.4 & 0 \\
\hline 27 Apr. & 3 & 15.8 & 1.9 \\
\hline 27 Apr. & 4 & 12.4 & 0 \\
\hline 29-30 Apr. & 15 & 14.2 & 34.5 \\
\hline 1 May & 8.5 & 12.0 & 0 \\
\hline 6-7 May & 9.5 & 12.2 & 0 \\
\hline 7 May & 3 & 17.8 & 0 \\
\hline 8 May & 7 & 14.3 & 0 \\
\hline 8-9 May & 16 & 17.1 & 0 \\
\hline 9-10 May & 11 & 16.0 & 6.9 \\
\hline 10-11 May & 14 & 16.1 & 1.0 \\
\hline 12 May & 5 & 14.4 & 0 \\
\hline 15-16 May & 10 & 11.2 & 17.3 \\
\hline 16-17 May & 22 & 10.4 & 81.8 \\
\hline
\end{tabular}

${ }^{\mathrm{z}}$ On 5 Apr., five pustules were first observed on elderberry plants. By 29 Apr., a total of 304 pustules were observed on 59 plants, and 350 total pustules on 63 plants were observed on 19 May.

Table 3. Mean number of Puccinia sambuci-infected leaves, leaflets, and rust pustules on 'Bob Gordon' elderberry plants at three distances from Carex frankii plants on 29 Apr. 2016.

\begin{tabular}{lccc}
\hline $\begin{array}{l}\text { Distance from } \\
\text { sedge }(\mathrm{cm})\end{array}$ & $\begin{array}{c}\text { No. of } \\
\text { pustules/plant }\end{array}$ & $\begin{array}{c}\text { No. of infected } \\
\text { leaves/plant }\end{array}$ & $\begin{array}{c}\text { No. of infected } \\
\text { leaflets/plant }\end{array}$ \\
\hline 23 & $7.6 \mathrm{a}$ & $3.3 \mathrm{a}$ & $5.8 \mathrm{a}$ \\
59 & $1.7 \mathrm{~b}$ & $1.7 \mathrm{~b}$ & $2.5 \mathrm{~b}$ \\
95 & $2.8 \mathrm{ab}$ & $2.8 \mathrm{ab}$ & $3.4 \mathrm{ab}$ \\
\hline
\end{tabular}

${ }^{\mathrm{z}}$ Values represent 24 replications of each spacing from sedge. Means followed by different letters in columns are significantly different according to Fisher's protected least significant difference test $(P \leq$ $0.05)$.

Table 4. Fruit characteristics, berry puree composition, and shoot dry weight of 'Bob Gordon' elderberry plants with or without Puccinia sambuci rust infection in $2016 .^{\mathrm{z}}$

\begin{tabular}{lccccc}
\hline & $\begin{array}{c}\text { Fruit } \\
\text { yield/plant }(\mathrm{g})\end{array}$ & $\begin{array}{c}\text { Berry } \\
\text { wt }(\mathrm{mg})\end{array}$ & $\begin{array}{c}\text { Total soluble } \\
\text { solids }\left({ }^{\circ} \text { Brix }\right)\end{array}$ & $\begin{array}{c}\text { Titratable } \\
\text { acidity }(\mathrm{g} / 100 \mathrm{~mL})\end{array}$ & $\begin{array}{c}\text { Shoot dry } \\
\mathrm{wt}^{\mathrm{y}}(\mathrm{g})\end{array}$ \\
\hline Rust-infected & $84 \mathrm{~b}$ & $116 \mathrm{~b}$ & $10.6 \mathrm{a}$ & $0.68 \mathrm{a}$ & $49 \mathrm{a}$ \\
Uninfected & $121 \mathrm{a}$ & $127 \mathrm{a}$ & $11.2 \mathrm{a}$ & $0.48 \mathrm{a}$ & $31 \mathrm{~b}$ \\
\hline
\end{tabular}

${ }^{\mathrm{z} P o o l e d ~ d a t a ~ f r o m ~ r u s t-i n f e c t e d ~ e l d e r b e r r y ~ p l a n t s ~}(\mathrm{n}=42)$ and noninfected plants $(\mathrm{n}=12)$ were subjected to a $t$ test. Means followed by different letters in columns are significantly different $(P \leq 0.05)$. Means were separated by a Satterthwaite test when variances were unequal or by a pooled test when variances were equal. Rust-infected plants averaged six pustules per plant on 19 May 2016.

${ }^{\mathrm{y}}$ Shoots harvested $10 \mathrm{~cm}$ above the medium surface on 10 Oct. 2016.

Table 5. Fruit characteristics, berry puree composition, leaf loss, and cane dry weight of 'Wyldewood' elderberry canes with or without Puccinia sambuci rust infection in $2016 .{ }^{\mathrm{z}}$

\begin{tabular}{lcccccc}
\hline & $\begin{array}{c}\text { Fruit } \\
\text { yield/cane }(\mathrm{g})\end{array}$ & $\begin{array}{c}\text { Berry } \\
\text { wt }(\mathrm{mg})\end{array}$ & $\begin{array}{c}\text { Total soluble } \\
\text { solids }\left({ }^{\circ} \text { Brix }\right)\end{array}$ & $\begin{array}{c}\text { Titratable } \\
\text { acidity }(\mathrm{g} / 100 \mathrm{~mL})\end{array}$ & $\begin{array}{c}\text { Leaf } \\
\text { loss }(\text { no. })\end{array}$ & $\begin{array}{c}\text { Cane dry } \\
\text { wt }(\mathrm{g})\end{array}$ \\
\hline Rust-infected & $47 \mathrm{~b}$ & $43 \mathrm{a}$ & $10.9 \mathrm{a}$ & $0.68 \mathrm{~b}$ & $19 \mathrm{a}$ & $58 \mathrm{a}$ \\
Uninfected & $88 \mathrm{a}$ & $41 \mathrm{a}$ & $11.7 \mathrm{a}$ & $0.78 \mathrm{a}$ & $10 \mathrm{~b}$ & $86 \mathrm{a}$ \\
\hline
\end{tabular}

${ }^{\mathrm{z}}$ Pooled data from rust-infected elderberry plants $(\mathrm{n}=33)$ and noninfected plants $(\mathrm{n}=11)$ were subjected to a $t$ test. Means followed by different letters in columns are significantly different $(P \leq 0.05)$. Means were separated by a Satterthwaite test when variances were unequal or by a pooled test when variances were equal. Rust-infected plants averaged 137 pustules/cane. pustules were recorded on elderberry plants according to the evaluation performed on 19 May 2016, indicating that additional infection may have occurred at hourly temperatures as high as $17.8^{\circ} \mathrm{C}$. Based on the results of the 2014 and 2016 studies, P. sambuci infection on elderberry plants may occur at temperatures between 9 and $18{ }^{\circ} \mathrm{C}$ with adequate relative humidity and moisture. During Spring 2016, potted 'Bob Gordon' elderberry plants developed few pustules compared with 'Wyldewood' plants of the field planting. This difference may be attributed the smaller size of elderberry plants used in the inoculation study, or perhaps a lower level of inoculum (i.e., teliospores) on alternate sedge hosts.

On other plants, such as asparagus, pycnia and aecia of Puccinia asparagi can develop on stems with at least $3 \mathrm{~h}$ of continuous wetting with temperatures ranging from 10 to $30{ }^{\circ} \mathrm{C}$ (Beraha et al., 1960). Maximum infection intensity of $P$. asparagi aecia occurred when mean temperatures remained between 19 and $22{ }^{\circ} \mathrm{C}$ for several days (Beraha et al., 1960). Both P. sambuci and $P$. asparagi occur during early spring; however, similarities in fungal spore germination and the subsequent infection of hosts by these two pathogens under identical environmental conditions are unknown and have not been investigated.

Elderberry plant proximity to the alternate host plants also influenced the incidence of rust infection, with those located closest to the sedge developing more pustules. These results suggest that rust infection can be reduced by elimination of the alternate host within or near elderberry plants. However, because many Carex species are perennial plants that spread by rhizomes (Mohlenbrock, 1999), eradication by mechanical means can be difficult.

Results from these studies indicate that the effect of $P$. sambuci on vegetative growth of elderberry plants varies with infection intensity, as measured by the pustule number. At low levels of infection (six pustules per plant), the number of leaves on 'Bob Gordon' near the end of the growing season was unaffected by $P$. sambuci. However, 'Bob Gordon' elderberry plants had more leaves early in the growing season and may have been more vigorous plants than the controls at the time of infection, resulting in infected plants with higher shoot weight on 10 Oct. (Table 3). Alternatively, a mean infection of six pustules per plant may not have been great enough to reduce shoot dry weight.

In experiments in which $P$. sambuci infection was more severe, premature leaf loss occurred (Table 5). In the 2016 experiment, by 26 Aug., 'Wyldewood' canes averaging 137 pustules/cane lost nearly twice as many leaves compared with control canes. Rustinfected 'Wyldewood' canes also had shoot dry weight that was $28 \mathrm{~g}$ less than that of controls on 13 Oct. (Table 5). Because shoot dry weights were limited to tissue removal at $10 \mathrm{~cm}$ above the potting medium surface, and plants varied in the number of stems, 
statistical differences among rust-infected and control canes may not have been detected during this experiment. However, vegetative growth (evaluated by dry weight) was reduced when 'Bob Gordon' elderberry plants averaged 690 pustules/plant at the end of the first growing season. Plant dry weight of these elderberry plants was also adversely affected during the successive growing season without $P$. sambuci reinfection (Table 1).

All levels of $P$. sambuci infection in these experiments resulted in loss of fruit yield. For young potted 'Bob Gordon' plants averaging 6 and 690 pustules/plant, there were $23 \%$ and $31 \%$ reductions in fruit yield, respectively (Tables 1 and 4). Threeyear-old 'Wyldewood' plants, with an average of 137 pustules/cane, had $47 \%$ less fruit weight than controls at harvest (Table 5). The greater yield loss from rust-infected 'Wyldewood' plants may be attributed to cultivar differences, plant age, or the unrestricted root growth in the field as compared with younger containergrown plants. Using a typical planting density (2688 plants/ha), berry yields reported herein, and a selling price of $\$ 2.27 / \mathrm{kg}$ of fruit (M. Warmund, personal communication), the estimated loss of income due to rust infection is \$225 to \$256/ha for 'Bob Gordon' and \$1250/ ha for 'Wyldewood' (assuming five canes per plant with similar berry weight). These estimated losses are likely conservative, as fruit yields for field-grown 'Bob Gordon' plants in Oregon have exceeded $5 \mathrm{~kg} /$ plant (Finn et al., 2008).

Soluble solids contents of berry puree from elderberry plants were not statistically different in any of the experiments. Due to the naturally low soluble solids content of elderberry fruit, sweeteners are added during processing to enhance the palatability of value-added products (Warmund et al., 2016). P. sambuci infection also did not affect the $\mathrm{pH}$, but the titratable acidity of the berry puree was lower than that of control samples when fruit was harvested from elderberry plants averaging 690 rust pustules/ plant or 137 pustules/cane. The lower titratable acidity of puree resulting from $P$. sambuci infection would alter the sugar-acid balance and may adversely affect the flavor of processed elderberry juice or wine products compared with juice products from uninfected fruit.

In conclusion, $P$. sambuci infection of elderberry plants occurred during early spring when sedge plants were in close proximity. Conditions favorable for possible infection were 9 to $18{ }^{\circ} \mathrm{C}, \geq 3 \mathrm{~h}$ continuous leaf wetness, and $\geq 85 \%$ relative humidity. Low infection rates of $P$. sambuci (six pustules per plant) did not adversely affect vegetative growth, even on young elderberry plants, whereas higher infection levels (137/pustules/cane) resulted in premature leaf loss. In contrast, low infection levels of rust resulted in fruit yield loss. Because of the potential for fruit yield loss on elderberry plants at relatively low infection levels, control of $P$. sambuci with fungicides may be warranted. Additionally, strategies that eliminate the alternate host or suppress its spread by underground rhizomes may be useful for reducing the leaf area on which rust inoculum resides, thereby limiting the potential for elderberry plant infection.

\section{Literature Cited}

Afshan, N.S. and A.N. Khalid. 2009. New records of Puccinia and Pucciniastrum from Pakistan. Mycotaxon 108:137-146.

Agrios, G.N. 2005. Plant pathology. 5th ed. Elsevier Academic Press, Burlington, MA.

Arthur, J.C. 1921. Memoranda and index of cultures of Uredineae. 1899-1917. Mycologia 13: 230-262.

Arthur, J.C. 1962. Manual of the rusts in the United States and Canada. Hafner Publishing, New York.
Beraha, L., M.B. Linn, and H.W. Anderson. 1960. Development of the asparagus rust pathogen in relation to temperature and moisture. Plant Dis. Rptr. 44:82-86.

Bolley, H.L. 1889. The heteroecismal Pucciniae. Amer. Monthly Microsc. J. 8:169-180.

Byers, P.L. and A.L. Thomas. 2011. 'Bob Gordon' elderberry. J. Amer. Pomol. Soc. 65:5255.

Byers, P.L., A.L. Thomas, and M. Millican. 2010 'Wyldewood' elderberry. HortScience 45:312313.

Charlebois, D., P.L. Byers, C.E. Finn, and A.L. Thomas. 2010. Elderberry: Botany, horticulture, potential. Hort. Rev. 37:213-280.

Finn, C.E., A.L. Thomas, P.L. Byers, and S. Serçe. 2008. Evaluation of American (Sambucus canadensis) and European (S. nigra) elderberry genotypes grown in diverse environments and implications for cultivar development. HortScience 43:1385-1391.

Kellerman, W.A. 1904. Uredineous infection experiments in 1904. J. Mycol. 11:26-33.

Littlefield, L.J. and M.C. Heath. 1979. Ultrastructure of rust fungi. Academic Press, New York.

Mims, C.W. 1981. SEM of aeciospore formation in Puccinia sambuci. Scan. Electron Microsc. 3:299-303.

Mohebalian, P.M., M.M. Cernusca, and F.X. Aguilar. 2012. Discovering niche markets for elderberry juice in the United States. HortTechnology 22: 556-566.

Mohlenbrock, R.H. 1999. The illustrated flora of Illinois. Sedges: Carex. Southern Illinois Univ. Press, Carbondale, IL.

Petersen, R. 1974. The rust fungus life cycle. Bot. Rev. 40:453-513.

Saccardo, P.A. 1891. Sylloge fungorum omnium hucusque cognitorum. R. Friedlander and Sohn, Berlin.

Warmund, M., M. Kwasniewski, J. Elmore, A Thomas, and K. Adhikari. 2016. Sensory attributes of juice from North American-grown elderberry cultivars. HortScience 51:1561-1565.

Warmund, M.R. 2017. Elderberry rust. Univ. Missouri Extension. 20 Oct. 2018. <https:// extension2.missouri.edu/ipm1036>.

Zomlefer, W.B. 1994. Guide to flowering plant families. Univ. North Carolina Press, Chapel Hill, NC. 